\title{
Evaluation of Ambient Air Quality Monitoring System in Jakarta: A Literatur Review
}

\author{
Michelle Gunawan $^{1}$, Riri Asyahira ${ }^{2}$, Filson M Sidjabat ${ }^{3}$ \\ ${ }^{1,2,3}$ Environmental Engineering Department, President University, Cikarang \\ *Correspondent email: michelle.natasya00@gmail.com
}

Received: December 14, 2019

Accepted:December 2019

\begin{abstract}
As the first step to air pollution control and public health protection, Air quality monitoring systems provides information that indicate the extend of pollution in an area, the source of pollution and the types of pollutants. Therefore, the aim of this study is to evaluate Jakarta's air quality monitoring system by comparing it to the US, which participates in Indonesia's air quality monitoring system by using their own system. In specific, parameters such as air quality index, monitoring stations, regulation and data availability are to be compared through reviewing various literatures in detail. The result obtained shows that the monitoring station amount is already ideal and complies to the U.S regulation. Indonesia's ambient air quality standard need to be stricter and Air Pollutant Standard Index should include $\mathrm{PM}_{2.5}$ as a parameter obtains significantly better results. Air quality data is available and accessible, although it needs to be integrated and provide real time information in a simple and effective way.
\end{abstract}

Keywords: Air Quality Monitoring System, Air Quality Index, Ambient Air, Monitoring Station, Air quality data

\begin{abstract}
Abstrak
Sebagai langkah pertama untuk mengendalikan polusi udara dan perlindungan kesehatan masyarakat, sistem pemantauan kualitas udara memberikan informasi yang menunjukkan perluasan polusi di suatu daerah, sumber polusi dan jenis-jenis polutan. Tujuan dari penelitian ini adalah untuk mengevaluasi sistem pemantauan kualitas udara Indonesia dengan membandingkannya dengan sistem Amerika Serikat yang berpartisipasi dalam sistem pemantauan kualitas udara di Indonesia. Secara khusus, parameter seperti indeks kualitas udara, stasiun pemantauan, regulasi dan ketersediaan data dibandingkan dengan cara meninjau berbagai literatur secara sistematis. Hasil yang diperoleh menunjukkan bahwa jumlah stasiun pemantauan sudah ideal dan sesuai dengan peraturan AS, standar kualitas udara ambien Indonesia harus lebih ketat, indeks standar pencemar udara parameter harus termasuk $\mathrm{PM}_{2.5}$ untuk mendapatkan hasil yang lebih signifikan, data kualitas udara tersedia dan dapat diakses tetapi perlu diintegrasikan dan diinformasikan secara real time dengan cara yang sederhana dan efektif.

Kata Kunci: Sistem Pemantauan Kualitas Udara, Indeks Kualitas Udara, Udara Ambient, Stasiun Pemantauan, Data kualitas udara
\end{abstract}

\section{Introduction}

Air as the world resources, has a big role for human life and other living things. Therefore its quality must be maintained from air pollutant. Air pollution is the emission of substances or other compounds into the ambient air that is created by anthropogenic activities at which point the quality of the ambient air is degraded which causes ambient air to not meet its function. While ambient air is defined as a free air on the surface of the earth in the troposphere layer which is needed and affects human health, living things and other environmental elements [1]. Thus, it is very critical to maintain good air quality by proper air quality monitoring system as the first step to control air pollution.

In general, air quality is assessed from the concentration of air pollution parameters which are measured higher or lower than the ambient air quality standard value. Air quality standard is a measure of the limit or the level of elements of air pollution that can be tolerated in the ambient air. The national ambient air quality standard is set as the maximum limit of ambient air quality to prevent air pollution [2]. 
The main objective of ambient air monitoring is to quantify and determine pollutants in the atmosphere. Air quality monitoring system is needed for obtaining reliable information of the air quality of an area [3]. Therefore, making it possible to decide on measures to better the air quality as well as provide to the public credible information of the state of the ambient air quality.

Air quality monitoring station is one of the critical components in an air quality monitoring system. The data obtained from this system is useful for evaluating air quality, understanding the health impact, validating dispersion models and studying the dynamic behavior of air pollutants. The correct placement and number of these stations are important in order to obtain a good data that is spatially representative [4]. There are two types of stations, Passive and Continuous. Indonesian regulations, requires an Automatic Ambient Air Quality Monitoring Station, defined as an ambient air quality monitoring station that operates continuously and the data can be monitored directly [5].

The purpose of measuring the air quality is to provide information that is easy to understand and as a basis for taking certain control measures. "Air quality index are meant to translate individual concentration measurements of a complex mixture of pollutants into a single figure indicating relative quality of the ambient air". This can be done in variety of ways including the health hazard level [6].

"The Air Pollution Standard Index is a number that does not have a unit that describes the condition of ambient air quality at a certain location and time based on the impact on human health, aesthetic values and other living things. The index functions as source of information to the public and material for consideration by the government to implement air pollution control measures" [5]. In addition, World Health Organization (WHO) on guidelines for Air Quality 2005 state that public information system is important in order to increase awareness, warn of pollution episodes, and advice susceptible populations [7]. Therefore, the availability and accessibility of the data in real time and condition is important.

DKI Jakarta is the capital city and the largest city in Indonesia which has an area of $622.33 \mathrm{~km}^{2}$ with a population of 10.374235 [8]. As a metropolitan city, the area is surrounded by high anthropogenic activity that emits air pollutant, therefore DKI Jakarta must have good air quality monitoring system in other side, and there are irregularities in air quality monitoring system that might be confusing to the public. On real time, 4 July 2019 at 13.00 P.M, the U.S Embassy provided information that the air quality of Jakarta is unhealthy, with the value 166 using parameter $\mathrm{PM}_{2.5}$ [9]. In contrast the information that is provided by the environment and forestry ministry hasn't been updated, the last update was on 3 July with the air quality information of Jakarta is moderate with air quality index 56 by parameter $\mathrm{PM}_{10}$ [10]. Thus, evaluation is needed in order to improve air quality monitoring system in DKI Jakarta.

The aim of this study is to evaluate DKI Jakarta's air quality monitoring system by comparing it to the US's system. In specific, parameters such as monitoring stations, ambient quality standards, air quality index and data availability and accessibility is to be compared through reviewing various literature in detail.

\section{Material and Methods}

This paper is a literature review that analyzed various sources in a systematical way to evaluate DKI Jakarta's air monitoring system by comparing it to the US's system which participates in Indonesia's air quality monitoring system by using their own system

The result and discussion contains discusses about evaluating the monitoring station amount and ideal number, national ambient air quality standard, comparison of standard air pollutant index with air quality index, and last is availability and accessibility of data.

\section{Results and Discussion Monitoring Station}

The ambient air quality monitoring method is generally carried out with automatic and continuous equipment, or manually. There are two types of automatic equipment, fixed station and mobile station. [11]. Out of all the monitoring stations in Jakarta, $86 \%$ is manual stations and $36 \%$ is continuous stations [12]. A study stated that continuous stations are deemed more suitable for Indonesia because it is not affected by the weather and can monitor continuously [13]. The number and location of monitoring station is an important consideration for an air quality monitoring network in order to guarantee that the measurements are thorough and good [12].

In Indonesia, the number of monitoring station is regulated in Regulation of The Environment Minister No 12 Year 2010. It is stated that there are two ways of determination, based on population or 
calculation. The first method is by comparing the population to the graph shown in Figure 1, this method is in particular for TSP, SOx, CO, HC, NOx monitoring.

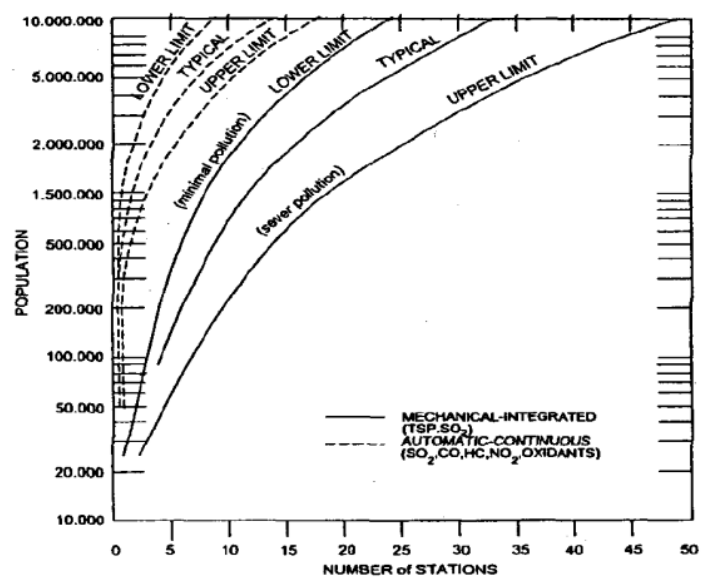

Fig. 1: Graph method to determining monitoring station Source: Regulation of The Environment Minister No 12 Year 2010

The second method is calculated using the equations below although, this method is used only for $\mathrm{SO}_{2}$ and TSP.

$$
\begin{aligned}
& \mathrm{N} \ldots=\mathrm{Nx}+\mathrm{Ny}+\mathrm{Nz} \\
& \mathrm{Nx}=0.0965 \frac{C m-C s}{C s} \mathrm{X} \\
& \mathrm{Ny}=0.0965 \frac{C s-c b}{C s} \mathrm{Y} \\
& \mathrm{Nz}=0.0004 \mathrm{Z} \text {. }
\end{aligned}
$$

United States EPA regulates the number of $\mathrm{PM}_{10}$ monitoring stations based on the population of an area and the level of pollution. The classification is listed in Table 1, It is said that, "Levels of "Low" refers to areas whose ambient $\mathrm{PM}_{10}$ concentrations are below $80 \%$ of the National Ambient Air Quality Standard (NAAQS), whereas "High" refers to areas whose ambient $\mathrm{PM}_{10}$ concentrations exceed the NAAQS by $20 \%$ or more." [14]

Table 1. US EPA Guideline for number of $\mathrm{PM}_{10}$ sampling points

\begin{tabular}{lcc}
\hline Population (thousands) & Low & High \\
\hline $100-250$ & 0 & $1-2$ \\
$250-500$ & $0-1$ & $3-4$ \\
$500-1,000$ & $1-2$ & $4-8$ \\
$>1,000$ & $2-4$ & $6-10$ \\
\hline \multicolumn{2}{c}{ Source: US EPA 40 CFR Part 58 (1979) }
\end{tabular}

DKI Jakarta, a developing Asian city, its pollution levels may be considered as 'high'. Because of the stricter air quality guidelines in the US compared to Asia. Jakarta has a population of 10,374,235 [8] In ideal conditions, Jakarta should have between 6-10 monitoring stations. Currently, there are a total of 15 monitoring stations in Jakarta, although currently only 8 stations is active [10]. This number still comply to the US's standards.

A recent study tried to find the ideal number of stations that should be built in Jakarta. The parameters used to determine this number is the potential location for the station, zoning, population density, surrounding land cover, and ease of access and permission. From their analysis, 53 ideal sites for air quality monitoring is found in Jakarta [13]. 


\section{Ambient Air Quality Standard}

Air quality standard is another important aspect in an air quality monitoring network. In Indonesia, the standard is regulated in Government Regulation No. 41 year 1999. It regulates 9 pollutants and 4 pollutants that is specified for chemical industries. While in the US, the ambient air quality standard is regulated in the National Ambient Air Quality Standard (NAAQS). According to EPA's website, the NAAQS includes six criteria [15]. In terms of the type of pollutants, NAAQS only regulates criteria pollutants while Indonesia regulates other pollutants such as, TSP, Dustfall, Fluorides, Chlorine and Sulfate.

By seeing the standards, it is found that the majority of the US's standards is stricter than Indonesian regulations as shown in Table 2. This stricter regulation is preferred because, human health and the environment certainly would benefit from it. In a study done in California [16], it was concluded that stricter ozone standards had a positive impact on Ponderosa pine growth. This study serves as an example and motivation for implementing stricter standards. It is in the citizen and environment's best interest if the Indonesian government are willing to set a stricter ambient air pollution standard.

Table 2. Ambient air quality standard

\begin{tabular}{|c|c|c|c|c|}
\hline \multirow[b]{2}{*}{ Pollutant } & \multicolumn{2}{|c|}{ Indonesia Regulation } & \multicolumn{2}{|c|}{ US Regulation (NAAOS) } \\
\hline & Sampling Time & Level & Sampling Time & Level \\
\hline \multirow{3}{*}{$\mathrm{SO} 2$} & 1 Hour & $900 \mu \mathrm{g} / \mathrm{Nm} 3$ & 1 Hour & $75 \mathrm{ppb}(75 \mu \mathrm{g} / \mathrm{Nm} 3)$ \\
\hline & 24 Hour & $365 \mu \mathrm{g} / \mathrm{Nm} 3$ & 3 Hours & $0.5 \mathrm{ppm}(500 \mu \mathrm{g} / \mathrm{Nm} 3)$ \\
\hline & 1 Year & $60 \mu \mathrm{g} / \mathrm{Nm} 3$ & & \\
\hline \multirow{3}{*}{$\mathrm{CO}$} & 1 Hour & $30,000 \mu \mathrm{g} / \mathrm{Nm} 3$ & 1 Hour & $35 \mathrm{ppm}(35,000 \mu \mathrm{g} / \mathrm{Nm} 3)$ \\
\hline & 24 Hour & $10,000 \mu \mathrm{g} / \mathrm{Nm} 3$ & 8 Hour & $9 \mathrm{ppm}(9,000 \mu \mathrm{g} / \mathrm{Nm} 3)$ \\
\hline & 1 Year & - & & \\
\hline \multirow{3}{*}{$\mathrm{NO} 2$} & 1 Hour & $450 \mu \mathrm{g} / \mathrm{Nm} 3$ & 1 Hour & $100 \mathrm{ppb}(100 \mu \mathrm{g} / \mathrm{Nm} 3)$ \\
\hline & 24 Hour & $150 \mu \mathrm{g} / \mathrm{Nm} 3$ & - & \\
\hline & 1 Year & $100 \mu \mathrm{g} / \mathrm{Nm} 3$ & 1 Year & $53 \mathrm{ppb}(53 \mu \mathrm{g} / \mathrm{Nm} 3)$ \\
\hline \multirow{2}{*}{$\mathrm{O} 3$} & 1 Hour & $235 \mu \mathrm{g} / \mathrm{Nm} 3$ & 8 Hours & $0.070 \mathrm{ppm}(70 \mu \mathrm{g} / \mathrm{Nm} 3)$ \\
\hline & 1 Year & $50 \mu \mathrm{g} / \mathrm{Nm} 3$ & & \\
\hline \multirow{2}{*}{$\mathrm{Pb}$} & 24 Hour & $2 \mu \mathrm{g} / \mathrm{Nm} 3$ & 3 month Average & $0.15 \mu \mathrm{g} / \mathrm{m} 3$ \\
\hline & 1 Year & $1 \mu \mathrm{g} / \mathrm{Nm} 3$ & & \\
\hline \multirow[t]{2}{*}{ PM 10} & 24 Hour & $150 \mu \mathrm{g} / \mathrm{Nm} 3$ & 24 Hour & $150 \mu \mathrm{g} / \mathrm{Nm} 3$ \\
\hline & 24 Hour & $65 \mu \mathrm{g} / \mathrm{Nm} 3$ & 24 Hour & $35 \mu \mathrm{g} / \mathrm{Nm} 3$ \\
\hline \multirow[t]{2}{*}{ PM 2.5} & 1 Year & $15 \mu \mathrm{g} / \mathrm{Nm} 3$ & 1 Year (Primary) & $12 \mu \mathrm{g} / \mathrm{Nm} 3$ \\
\hline & & & 1 Year (Secondary) & $15 \mu \mathrm{g} / \mathrm{Nm} 3$ \\
\hline \multirow[t]{2}{*}{$\mathrm{HC}$} & 3 Hour & $160 \mu \mathrm{g} / \mathrm{Nm} 3$ & - & - \\
\hline & 24 Hour & $230 \mu \mathrm{g} / \mathrm{Nm} 3$ & - & - \\
\hline TSP & 1 Year & $90 \mu \mathrm{g} / \mathrm{Nm} 3$ & - & - \\
\hline Dustfall & 30 Days & $\begin{array}{l}10 \text { Ton/Km2/Month } \\
\text { (Domestic) } \\
20 \text { Ton/Km } 2 / \text { Month } \\
\text { (Industrial) }\end{array}$ & & \\
\hline Total & 24 Hour & $3 \mu \mathrm{g} / \mathrm{Nm} 3$ & - & - \\
\hline Fluorides* & 90 Days & $0.5 \mu \mathrm{g} / \mathrm{Nm} 3$ & & \\
\hline $\begin{array}{l}\text { Fluor Indeks* } \\
\text { Chlorine \& }\end{array}$ & 30 Days & $40 \mu \mathrm{g} / 100 \mathrm{~cm} 3$ & - & - \\
\hline $\begin{array}{l}\text { Chlorine } \\
\text { Dioxide* }\end{array}$ & 24 Hour & $150 \mu \mathrm{g} / \mathrm{Nm} 3$ & - & - \\
\hline Suphat Indeks* & 30 Days & $1 \mathrm{mg} \mathrm{SO} 3 / 100 \mathrm{~cm} 3$ & - & - \\
\hline
\end{tabular}

\section{Standard Air Pollutant Index}

Air Quality Index (AQI) provides air quality information that is easy to understand for public. Each country has different scales due to different standards. Most Asian and Southeast Asian countries uses the US model [6]. While Indonesia has its own model namely Standard Air Pollutant Index (Indeks Standar Pencemar Udara, ISPU) 
Air Quality Index in Jakarta uses the Indonesian model that is regulated in Decree of The Minister of State Environment No. KEP-45/MENLH/10/1997 about Standard Air Pollutant Index (ISPU). The index data is obtained from automatic ambient air quality monitoring station with parameters consisting of Particulate matter $10\left(\mathrm{PM}_{10}\right)$, Carbon Monoxide (CO), Sulphur Dioxide $\left(\mathrm{SO}_{2}\right)$, Nitrogen Dioxide $\left(\mathrm{NO}_{2}\right)$ and Ozone $\left(\mathrm{O}_{3}\right)$ [5]. On the attachment it is provided about range of index values and its category with an explanation of the health impact as shown in Table 2.

In 1976 USA introduced an air quality index named Pollutant Standards Index, the pollutant parameters are similar with Standard Air Pollutant Index (ISPU). AQI is also similar with ISPU in descriptive categories and range of index value as shown in figure above. In 1999, PSI was revised by U.S EPA, and is renamed to Air Quality Index (AQI) and there was an addition of pollutant parameter with $\mathrm{PM}_{2.5}$ [5]. This additional parameter shows the difference with ISPU that still uses $\mathrm{PM}_{10}$ as one of the parameter. $\mathrm{PM}_{10}$ is an inhalable particle with a diameter of $10 \mathrm{~mm}$ that can enter deep into the lungs and bloodstream, while $\mathrm{PM}_{2.5}$, with $2.5 \mathrm{~mm}$ or smaller diameter, is a fine inhalable particle. For this reason, $\mathrm{PM}_{2.5}$ raises the greatest risk [17]

Table 3. Range index value and its category description

\begin{tabular}{|c|c|c|}
\hline Category & Range & Description \\
\hline Good & $0-50$ & $\begin{array}{l}\text { Air quality level does not affect } \\
\text { humans or animals and does not } \\
\text { impact plants, buildings or aesthetic } \\
\text { value }\end{array}$ \\
\hline Moderate & $51-100$ & $\begin{array}{l}\text { Air quality level does not affect } \\
\text { humans or animals, but impacts } \\
\text { sensitive plants and aesthetic value }\end{array}$ \\
\hline Unhealthy & 101-199 & $\begin{array}{l}\text { Air quality level is harmful for } \\
\text { humans or animals that is sensitive or } \\
\text { can cause damage to plants or } \\
\text { aesthetic value }\end{array}$ \\
\hline Very Unhealthy & $200-299$ & $\begin{array}{l}\text { Air quality level can be detrimental to } \\
\text { health in a number of segments of the } \\
\text { population that are exposed }\end{array}$ \\
\hline Dangerous & $<300$ & $\begin{array}{l}\text { Air quality level dangerous can } \\
\text { generally can cause health problems in } \\
\text { the population }\end{array}$ \\
\hline
\end{tabular}

Source : KEP-45/MENLH/10/1997

In fact, when evaluated based on Standard Air Pollutant Index, air quality of DKI Jakarta is categorized as moderate with critical parameter $\mathrm{PM}_{10}$. At the same time, when evaluated by Air Quality Index, DKI Jakarta is categorized as unhealthy with critical parameter $\mathrm{PM}_{2.5}$. Thus, it is not surprising that all government sites that convey air quality do not state that the air quality is not healthy. This could potentially cause misunderstandings about the actual status of air quality and potentially inhibit the public to take preventive measures.

Calculating method of standard measured Air Pollutant Index (ISPU) is regulated in Decree of the Head of Bapedal No. 107 of 1997 [18] is similar with US Air Quality Index (AQI) calculation method and the highest index value will be reported, the only difference is in symbols. Both are done by standard formula shown in equation 5:

$$
\mathrm{I}=\frac{I a-I b}{X a-X b}(X x-X b)+I
$$

I $=$ ISPU counted

Ia = ISPU upper limit

$\mathrm{Ib}=$ ISPU lower limit

$\mathrm{Xa}=$ Ambient upper limit

$\mathrm{Xb}=$ Ambient lower limit

$\mathrm{Xx}=$ Real ambient level of measurement results ( $\mathrm{ppm}, \mathrm{mg} / \mathrm{m}^{3}$ ). 


\section{Evaluating Data}

The official government public media that informs the public about the air quality index data of DKI Jakarta is analysed at the same time on Sunday, 7 July 2019 at 12.30 P.M which are the Environmental Management agency of the capital Jakarta, Ministry of Environment and Forestry, BMKG, The official portal of the DKI Jakarta provincial government named Jakarta Smart city, and the data developed by U.S Environment Protection Agency (EPA) collected by US embassy is used as a comparison that is the Air Quality Index (AQI).

From availability and accessibility analysis point of view, there are six government official sites that shows Air Quality Index DKI Jakarta. First is air quality index data available from Ministry of Environment and Forestry sites shown in Figure 2, but the last update was on 3 July 2019 at 15.00 P.M it means that the data is not in real time. Second is data from Environmental Management Agency of the Capital Jakarta's site shown in Figure 3, the last update of air quality index data was on 6 July 2019 at 15.00 P.M, it means the data is not in real-time and the sites does not show the categorical explanation.

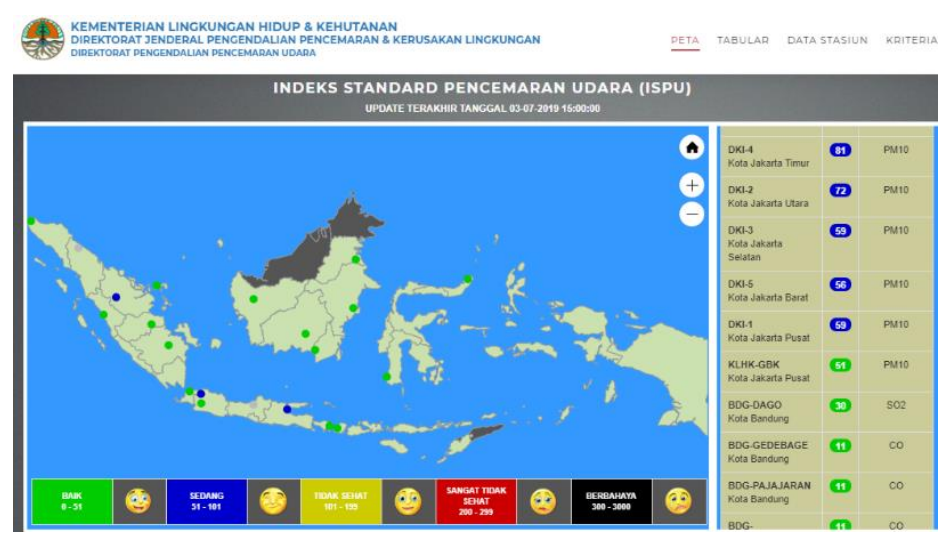

Fig 2: Data from Ministry of Environment and Forestry Sites Source: [19]

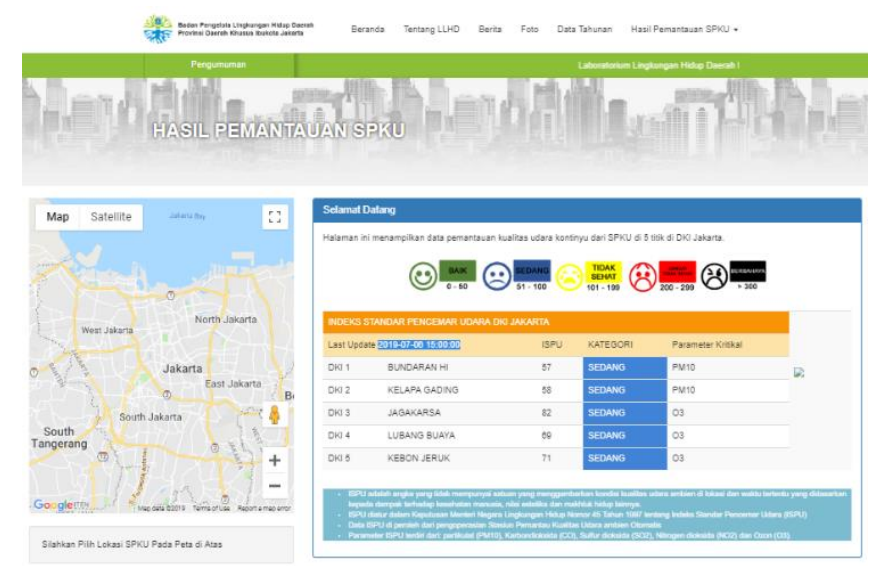

Fig 3: Data from Environmental Management agency of the capital Jakarta Source: [20]

Third, data from BMKG shown in Figure 4 which was last updated on 7 July 2019 means the data is on a real time, but the sites do not show air pollution standard index, it shows concentration with unit, this is not in line with the state minister of environment No. KEP-45/MENLH/10/1997. Fourth, air quality index data from official portal of DKI Jakarta provincial government named Jakarta Smart City shown in Figure 5 is using data from from Environmental Management Agency of the Capital Jakarta sites. In contrast, the integrated data presented by U.S EPA in AQI sites shown in Figure 6, Air quality Index is updated on Sunday 7 July 2019 at 12.00 , means the data availability is on a real time. 


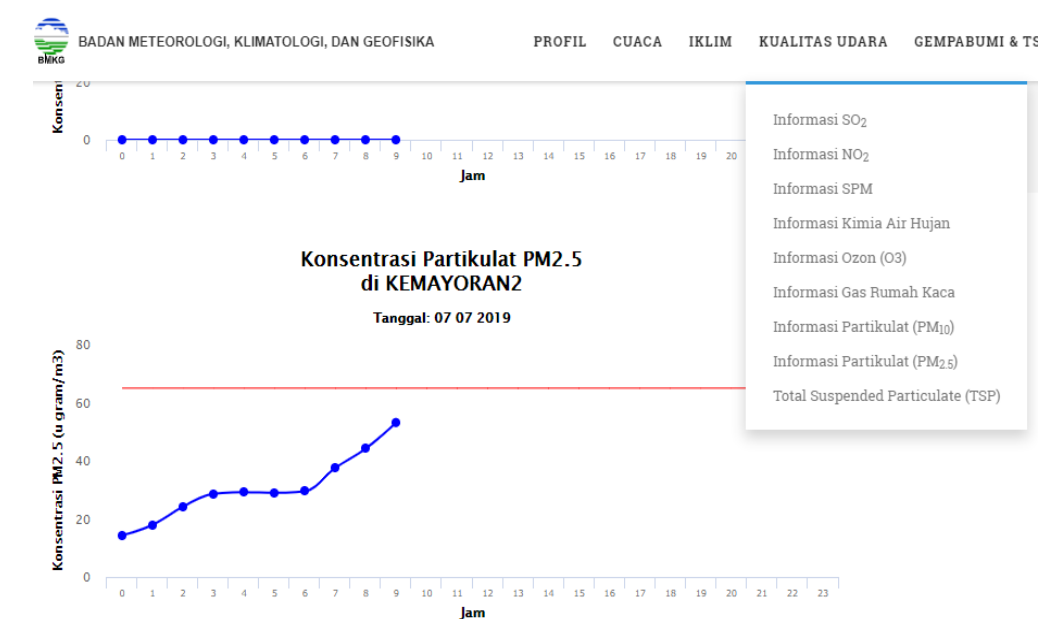

Fig 4: Data from $B M K G$

Source: [21]

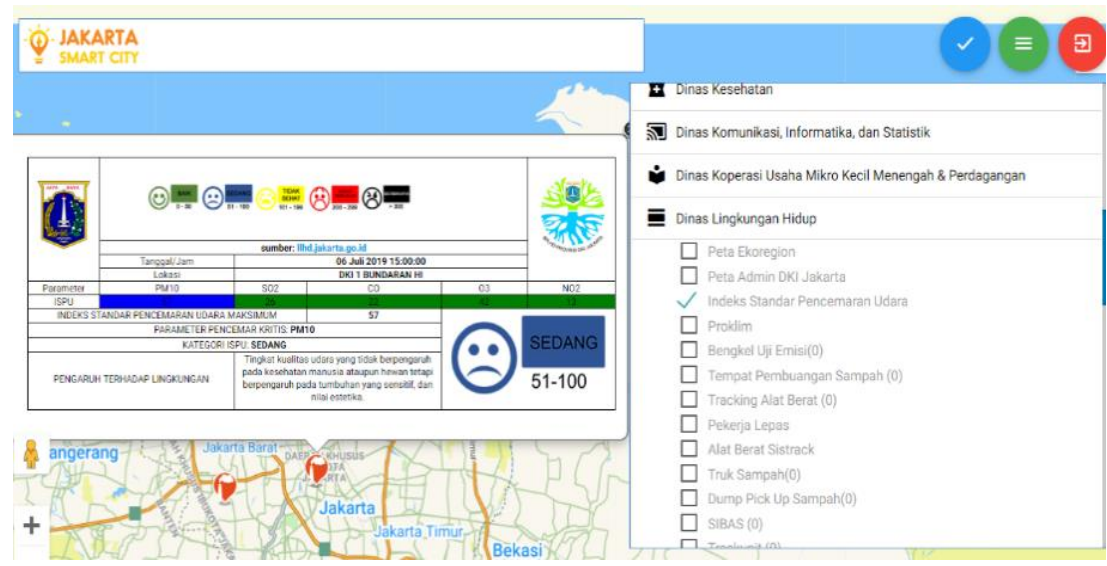

Fig 5: Data from The official portal of the DKI Jakarta provincial government which namely Jakarta Smart City Source: [22]

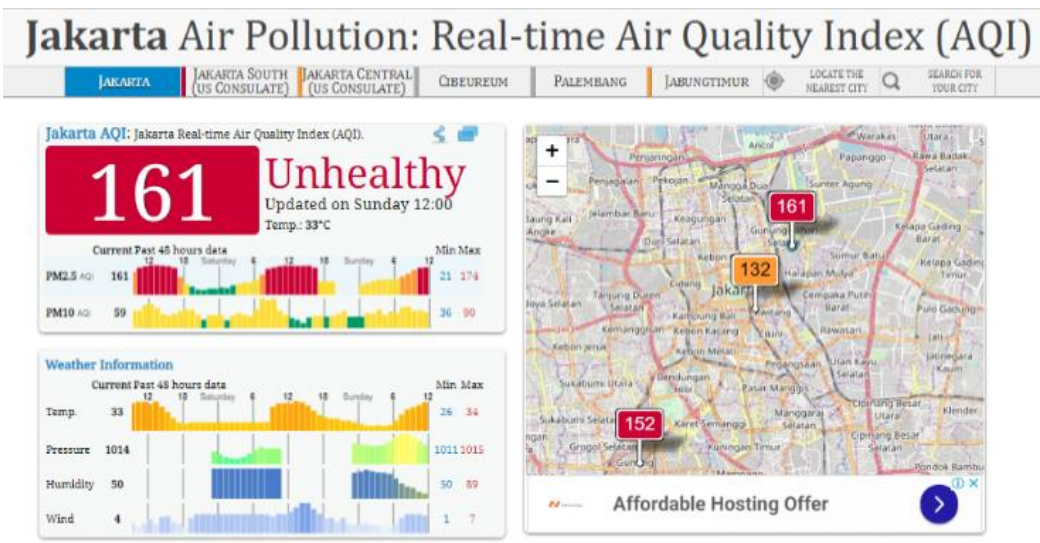

Fig 6: Data from U.S EPA AQI sites

Source: [23]

The institution that is obligated to calculate and inform the Air Pollution Standard Index to the public nationally every day is the head of Environmental Impact Control Agency. Informing Air quality index is carried through public media electronics, and display boards in certain public places. The data that is informed is taken from the average data of previous 24 hours and its valid for the next 24 hours [5]. While U.S Environment Protection Agency (EPA) provides a uniform, simple data that is integrated data from own monitoring and is also supported by other federal agencies each hour, for reporting air quality data to the public [7].

The institution that is obligated to calculate and inform the Air Pollution Standard Index to the public nationally every day is the head of Environmental Impact Control Agency. Informing Air quality index is carried through public media, electronics, and display boards in certain public places. The data 
that is informed is taken from the average data of previous 24 hours and its valid for the next 24 hours [5]. While U.S Environment Protection Agency (EPA) provides a uniform, simple data that is integrated data from own monitoring and is also supported by other federal agencies each hour, for reporting air quality data to the public [7].

In brief, Indonesia's air quality index data is available and easy to access but data is not integrated, not in a real time, and not uniform in the time and index value even though it was visited at the same time. This is different with data presented by the U.S EPA in AQI. It will better if Indonesian government adopt US EPA rule where data is integrated and informed in a real time each hour.

Indonesia is classified as a developing country. In recent times, Developing countries are installing air quality monitoring system and beginning to forecast air pollution to provide information to government and public [7]. The next critical step is to make policies that focus on effective communication of data, education of the public about air quality conditions, presenting an integrated data through data exchange with other organizations. Providing integrated data in real-time and forecasting air quality data is critical for public information, it will ease the process of understanding the potential harmful conditions and will encourage the fulfilment of the sustainable development goals in Jakarta.

Improving policy on monitoring stations and air quality reporting will provide a strong basis for taking further action on air pollution control measures. An accurate description of the status of the ambient air quality would enable the local government to take appropriate measures and strategies for adaptation or mitigation of air pollution. Policies that already succeed in other countries can be considered to be implemented in Jakarta as means to improve air quality.

A study done shows that the air pollution in Beijing has improved by $55.74 \%$ after the air quality policies are implemented [24]. The notable policies are:

- Replacing coal energy with clean energy

- Retiring old vehicles

- Forbidding high-emission vehicles to drive in highly polluted days

- Cleaning up heavy pollution companies

In relation with vehicular emission, Singapore provides a successful precedent with its policies. Singapore combines traffic management, promotion of public transport and regulatory policies to reduce the number of cars [25]. Policies such as road-pricing schemes, vehicle inspection and elimination of old cars can be considered to be implemented in Jakarta. Though further studies need to be conducted in order to determine whether the policies are feasible to be applied in Jakarta or not. To Summarize, Indonesia and US has some similarity, as shown in Table 4. Although, it is clear that the US's system is stricter compared to Indonesia.

Table 4. Summary of comparison

\begin{tabular}{|c|c|c|}
\hline Parameters & Indonesia & U.S \\
\hline Monitoring Station Number & $\begin{array}{l}\text { Based on population or } \\
\text { calculation }\end{array}$ & $\begin{array}{l}\text { Based on the } \\
\text { population of an } \\
\text { area and the level } \\
\text { of pollution }\end{array}$ \\
\hline Ambient Air Quality & \multicolumn{2}{|c|}{$\begin{array}{l}\text { The majority of the US's standards level is stricter } \\
\text { than Indonesian regulations }\end{array}$} \\
\hline $\begin{array}{l}\text { Pollutant Index } \\
\text { Parameters }\end{array}$ & $\mathrm{PM}_{10}, \mathrm{CO}, \mathrm{SO}_{2}, \mathrm{NO}_{2}, \mathrm{O}_{2}$ & $\begin{array}{l}\mathrm{PM}_{2.5}, \mathrm{PM}_{10} \mathrm{CO} \\
\mathrm{SO}_{2}, \mathrm{NO}_{2}, \mathrm{O}_{2}\end{array}$ \\
\hline Data Accessibility & $\begin{array}{l}\text { Data that is informed is not } \\
\text { integrated and taken from the } \\
\text { average data of previous } 24 \\
\text { hours and its valid for the } \\
\text { next } 24 \text { hours }\end{array}$ & $\begin{array}{l}\text { The data is } \\
\text { integrated and } \\
\text { informed each } \\
\text { hour }\end{array}$ \\
\hline
\end{tabular}

\section{Conclusion}

Based on this discussion, Jakarta's air quality monitoring system has already met the standard. But, it still can be improved, for the most part by adding more stations and having more continuous stations. It is recommended that the Indonesian government review the National Ambient Air Quality Standards 
(NAAQS) based on recent studies and possibly make a stricter standard. In addition, it is necessary to include $\mathrm{PM}_{2.5}$ to the pollutant parameter of Standard Air Pollutant Index (ISPU). Because $\mathrm{PM}_{2.5}$ is a fine inhalable particle that raises a greater risk than $\mathrm{PM}_{10}$ and serves as a critical parameter in DKI Jakarta based on U.S embassy air quality data. Air quality index data information is available and accessible but data is not integrated, not in a real time and not uniform at the same time. Therefore, it is highly recommended to effectively communicating integrated air quality data in a real time and forecast air quality data, following by educating the public about air quality conditions and effective emission reduction program. This can be done through proper policy-making about air quality monitoring and air quality index. The local government may consider implementing new policies that is successful in other countries. It is important for further studies on the suitability with the current situation of Jakarta.

\section{Acknowledgment}

The Authors would like to thank our colleagues from President University who provided insight and expertise that greatly assisted the research, although they may not agree with all of the interpretations/conclusions of this paper.

$\begin{array}{ll}\text { 6. Abbreviations } & \\ \text { WHO } & \text { World Health Organization } \\ T S P & \text { Total Suspended Particle } \\ \text { SO2 } & \text { Sulfur Dioxide } \\ C O & \text { Carbon Monoxide } \\ H C & \text { Hydrocarbon } \\ N O 2 & \text { Nitrogen Dioxide } \\ \text { NAAQS } & \text { National Ambient Air Quality Standard } \\ I S P U & \text { Indeks Standar Pencemar Udara } \\ \text { U.S EPA } & \text { United State Environmental Protection Agency }\end{array}$

7. References

[1] Indonesia No. 41 Tahun 1999 tanggal : 26 mei 1999 tentang Pengendalian Pencemaran Udara, Jakarta

[2] A. Kurniawan, "Pengukuran Parameter Kualitas Udara (CO, NO2, SO2, O3 Dan PM10) Di Bukit Kototabang Berbasis ISPU," Jurnal Teknosains, vol. 7, no. 1, p. 1, 2018.

[3] D. Vallero, Fundamentals Of Air Pollution. Place of publication not identified: Academic Press, 2014.

[4] T. Yu, W. Wang, P. Ciren, and R. Sun, "An assessment of air-quality monitoring station locations based on satellite observations," International Journal of Remote Sensing, vol. 39, no. 20, pp. 6463-6478, 2018.

[5] Keputusan Menteri Negara Lingkungan Hidup No. KEP-45/MENLH/10/1997 tentang Indeks Standar Pencemar Udara

[6] S. Lemes, “Air Quality Index (AQI) - Comparative Study And Assessment Of An Appropriate Model For B\&H.," 2018.

[7] Earthzine, "AIRNow-International: The Future of the United States Real-time Air Quality Reporting and Forecasting Program with GEOSS participation," IEEE Earthzine, 08-May-2018. [Online]. Available: https://earthzine.org/airnow-international-the-future-of-the-united-states-real-time-airquality-reporting-and-forecasting-program-with-geoss-participation-2. [Accessed: 06-Jul-2019].

[8] BPS Provinsi DKI Jakarta. [Online]. Available: https://jakarta.bps.go.id/publication/2018/08/16/67d90391b7996f51d1c625c4/provinsi-dkijakarta-dalam-angka-2018.html. [Accessed: 04-Jul-2019].

[9] The World Air Quality Index project, "Jakarta Air Pollution: Real-time Air Quality Index," aqicn.org. [Online]. Available: https://aqicn.org/city/jakarta/. [Accessed: 04-Jul-2019].

[10] “iku.menlhk.go.id - Indeks Kualitas Udara Perkotaan.” [Online]. Available: http://iku.menlhk.go.id/. [Accessed: 04-Jul-2019].

[11] Peraturan Menteri Negara Lingkungan Hidup. No 12 Tahun 2010 : tentang Pelaksanaan Pengendalian Pencemaran Udara di Daerah

[12] Asian Development Bank, "Improving Air Quality Monitoring In Asia: A Good Practice Guidance." 2013. 
[13] A. Riqqi, A. Fawaid, and D. Driejana, "Perancangan Potensi Lokasi Jejaring Stasiun Pemantau Kualitas Udara Di Daerah Urban Berbasis Data Spasial Studi Kasus di DKI Jakarta," Majalah Ilmiah Globe, vol. 21, no. 1, p. 27, 2019.

[14] US EPA 40 CFR Part 58 Appendix D. 2012.

[15] "NAAQS Table," EPA, 20-Dec-2016. [Online]. Available: https://www.epa.gov/criteria-airpollutants/naaqs-table. [Accessed: 04-Jul-2019].

[16] D. T. Tingey, W. E. Hogsett, E. H. Lee, and J. A. Laurence, "Stricter Ozone Ambient Air Quality Standard Has Beneficial Effect on Ponderosa Pine in California," Environmental Management, vol. 34, no. 3, pp. 397-405, 2004

[17] "Particulate Matter (PM) Basics," EPA, 14-Nov-2018. [Online]. Available: https://www.epa.gov/pmpollution/particulate-matter-pm-basics. [Accessed: 05-Jul-2019].

[18] Keputusan Kepala Badan Pengendalian Dampak Lingkungan No. 107 Tahun 1997 Tanggal 21 November 1997 Tentang : Perhitungan Dan Pelaporan Serta Informasi Indeks Standar Pencemar Udara, Jakarta

[19] "iku.menlhk.go.id - Indeks Kualitas Udara Perkotaan.” [Online]. Available: http://iku.menlhk.go.id/. [Accessed: 07-Jul-2019].

[20] Sistem Informasi Pengelolaan Pencemaran Udara. [Online]. Available: https://llhd.jakarta.go.id/pages/sensor/sensor.php. [Accessed: 07-Jul-2019].

[21] Informasi Konsentrasi Partikulat (PM2.5. [Online]. Available: https://www.bmkg.go.id/kualitasudara/informasi-partikulat pm25.bmkg. [Accessed: 07-Jul-2019].

[22] P. P. D. K. I. Jakarta, Indeks Standar Pencemar Udara. [Online]. Available: http://smartcity.jakarta.go.id/maps/. [Accessed: 07-Jul-2019].

[23] The World Air Quality Index project, "Jakarta Air Pollution: Real-time Air Quality Index," aqicn.org. [Online]. Available: https://aqicn.org/city/jakarta/. [Accessed: 07-Jul-2019]

[24] G. Yuan and W. Yang, "Evaluating China's Air Pollution Control Policy with Extended AQI Indicator System: Example of the Beijing-Tianjin-Hebei Region," Sustainability, vol. 11, no. 3, p. 939, Dec. 2019.

[25] Molina, Velasco, Retama, and Zavala, "Experience from Integrated Air Quality Management in the Mexico City Metropolitan Area and Singapore," Atmosphere, vol. 10, no. 9, p. 512, 2019. 